\title{
Impact of Technologies During COVID-19 Pandemic for Improving Behavior Intention to Use E-learning
}

\author{
https://doi.org/10.3991/ijim.v15i01.17847 \\ Ragad M Tawafak ${ }^{(\mathbb{})}$ \\ University Malaysia Pahang, Pahang, Malaysia \\ Al Buraimi University College, Al Buraimi, Oman \\ raghad@buc.edu. om \\ Ghaliya AlFarsi \\ Al Buraimi University College, Al Buraimi, Oman \\ Universiti Tenaga Nasional, Kajang Selangor, Malaysia \\ Jasiya Jabbar, Sohail Iqbal Malik, Roy Mathew, Abir AlSidiri \\ Al Buraimi University College, Al Buraimi, Oman \\ Mohanaad Shakir \\ University of Buraimi, Al Buraimi, Oman \\ Awanis Romli \\ University Malaysia Pahang, Pahang, Malaysia
}

\begin{abstract}
COVID-19 pandemic has adversely affected the whole world. Its impact on the education sector cannot be considered small. This study aims to explore the roles and effects of Technology-Enhanced Learning (TEL) in assisting pedagogy, abolishing technophobia among undergraduates, to overcome the pandemic and to prevent the near-total closure of education. The study conducted among undergraduate students. The smart learning practices of Middle East countries and TEL effectiveness of using Google meet, online communication, Blogging, PDF reports and presentation, free teaching and learning applications in enhancing behaviour intention of learning also enclosed in the article as innovative solutions. The effectiveness, challenges and recommendations of the e-learning system studied. The results revealed that the features of TEL spur and encourage the behaviour intention to use e-learning and technologies. The results show how the adoption of TEL helped to overcome the global lockdown of educational institutions which might have affected the student's future.
\end{abstract}

Keywords - COVID-19; TEL; Higher Education Institutions; Learning Environment; Student Performance 


\section{Introduction}

The COVID-19 is an ongoing worldwide pandemic of coronavirus. Even though it is a health crisis, it has a broad impact affecting various domains, general society, economy, education, culture, politics, etc. Initially, the education sector was in a point of closure. But as the pandemic is prolonging and a complete lockdown for education is impossible, the uncertainty forced Universities and schools to switch the mode of the education system from campus to home. Thus, the pandemic transformed teaching and learning from the traditional approach to a completely online way with numerous challenges for the authority [1]. Some of the challenges include how to revise and offer the programs to keep the same schedules and cover the objectives of course within the same academic year. How to how to provide necessary training and workshops to teachers and instructors to cope with the new teaching method, how to motivate and engage students to sit in class, etc.

Nowadays, undergraduate students and adults enclosed with technology innovations; their daily routines entwined with social media, mobile phones, tablets, and Internet use [2]. Technology proficiency has played a vital role in serving the current world situation. The dissemination of corona-virus that started from China has extended the whole world. Therefore, there is a severe need to know how the active use of e-learning can utilize to overcome this pandemic. Online education and smart technologies now incorporated in undergraduate programs, no sooner all have to integrate these technological innovations in their lives, tutoring, career, etc. [3-5]. To reach this point, each organization, enterprise or universities need to address clear policies on how to implement TEL within new standards [5]. Within a constricted time, the universities and international institutions still work on their approval of mounting TEL usage to prevent the lockdown of the education system $[6,9]$.

The primary objective of this study is to investigate a comprehensive review to explore the achievements of student learning by employing e-learning to overcome the coronavirus COVID-19 pandemic. Furthermore, evaluating the impact of using TEL to overcome the pandemic $[3,15,16]$. The effect of TEL in pedagogy in updating curriculum, teaching tools, assessment forms, examination methods, and student feedback [5, 16]. This research article structured into several parts- firstly, the research questions addressed in the study, followed by a literature review on related works. The next section comprises the smart technologies used in different countries and the different viewpoints. The article ends up with the discussion and conclusion of the study.

\section{Research Questions}

How can academic performance development give accurate results by finding the relationship between using TEL and the impact of behavioral intention to use e-learning system within the COVID-19 pandemic? The study needs to consider some factors such as faculty teaching tools, assessment methods and student satisfaction in learning and assessment. Thus, how COVID-19 pandemic affects the teaching and learning process? Secondary research questions: 
1. What is the TEL applied in colleges and universities in conjunction with improving lab equipment and administrative experience within the COVID-19 pandemic?

2. What recommendations used with TEL mechanism to convert to online teaching and learning?

3. What is the standard type of TEL data analysis mostly used in universities and colleges?

\section{$3 \quad$ Literature Review}

The computerized progress especially inspires this study that the COVID-19 pandemic is calling for including youngsters and their essential instruction. The new advanced change depends entirely on the technologies and enhancement of using e-learning as a revolution to overcome the COVID-19 pandemic. There are many determinant factors viable as a substitute irregular and its impact on the behaviour intention to trust the e-learning use and acceptance. In any case, they depended intently on developing science to change their contributions and endeavoured to address and explore some fundamental and social alterations to find the right elements to evaluate the learning impact with behaviour intention to use e-learning system.

This study highlights different types of software $s$ and platform used the TEL application system to improve the behaviour intention of using e-learning system as an alternative solution to learning during this pandemic situation. A study presented by Tawafak et al., (2019) explained in the past academic year, and the IT department proposed a novel strategy to use technologies in education through the activation of using Google classroom and uploaded many of recorded materials [4]. Furthermore, in this year of 2020, new adaptation did from upgrading the e-learning through activating Moodle as a common platform. The technology of evaluating the students through Moodle were all facilities are there of delay submission alarm, re-uploaded files indicator, excel files of all grades, online quizzes, using of URL to link the course with many exciting videos for further learning.

In the last few years back, the use of TEL as an educational tool for supporting courses and developing the academic performance has been a constant tool for discussion and apply by the teachers and ease of use by the students [40-45]. The majority of students how used these technologies can be randomly affected with their ability to trust and confidence to keep learning on different tools and varied versions [46].

However, the use of TEL with different applications could substantially improve the student behaviour intention to use e-learning and enhance the effectiveness of teachers and their teaching, to evaluate and services supported with these technologies [17]. [42] Show there is evidence to use TEL that has a significant impact on teaching natural sciences, through producing new ideas that not directly observed. The use of TEL provides the exact effect of the used variables through each model and its impact on teaching quality, student learning outcomes, teaching tools, quality assurance and university or organization outcomes [2, 4, and 15].

The COVID-19 pandemic appears a new problem with teaching circumstances. This pandemic situation points to the need for using more technologies and give many facilities to keep student interest in continuous learning and keep the typical standards of teaching objectives and outcomes. A study proposed by [4], the authors' recommended 
using Blog- video programs to attach a tutorial material as supported videos to help the weak students to remember the essential topics and to train more effectively within course requirement outside the class time.

Other studies given by [43-46], suggested using integration among technologies as a batch system to make access quickly and smoothly by the students within the same ticket by the organization account. Nevertheless, in some cases of practical courses as in IT and programming courses, the teachers found that integration technologies could affect negatively to the compilers of different software [45].

In some cases, discussed by $[2,4,8,10]$ that use the developed level of TEL and technologies adoption were difficult for teachers. Especially for senior teachers who are not familiar with new technologies and not comfortable to accept the different devices included to education process as the use of active e-learning system, mobile engagement, Facebook, and Instagram [46].

In the case of using distance learning to overcome coronavirus pandemic, the factors used by e-learning systems, mobile systems influences can contribute directly or indirectly on academic performance and student satisfaction. At the last step, the utterly new learning method and the full use and trust of using TEL in education have a strong influence on the university outcomes.

However, distinguish the critical requirements of developing a safe e-learning system acceptance, this study highlights the critical external factors should provide to be in e-learning circumstances. These factors such as the internet service availability, teachers training, student interest, and cloud computing to hold the full organization management control, trusted assessment tools, and full monitor to follow by quality assurance department. These external factors all work together to test the acceptance of use TEL with active e-learning system to motivate student behaviour intention to use e-learning system in the next coming years.

Table 1 summarize different types of technologies and a variety of platforms used as a type of e-learning to help student with distance learning circumstances and pandemic conditions.

Table 1. Summarized Studies

\begin{tabular}{|c|l|l|l|}
\hline No. & Technology Applied & \multicolumn{1}{|c|}{ Samples } & \multicolumn{1}{c|}{ Findings } \\
\hline$[4]$ & TEL & 58, Oman & Encourage students to use TEL and e-learning system \\
\hline$[42]$ & $\begin{array}{l}\text { Mobile Access } \\
+ \text { LMS }\end{array}$ & 122, Greece & Introduce innovation of teaching and learning process \\
\hline$[45]$ & ICT +TAM & 75, Greece & Effective use of ICT and smart Mobile devices in education \\
\hline$[43]$ & Mobile device +TAM & 125, Greece & $\begin{array}{l}\text { Introducing mobile device within classroom attendance as a } \\
\text { new type of teaching and learning method }\end{array}$ \\
\hline$[10]$ & E-learning system & 295, Oman & Developing continuous of system use with multi platforms \\
\hline$[20]$ & TAM + MOOC & 295, Oman & $\begin{array}{l}\text { Developed TAM and TAM2 feature for enhancing MOOC } \\
\text { features and use }\end{array}$ \\
\hline$[1]$ & LMS, Health system &,-- China & Impact of COVID -19 to educational future \\
\hline$[3]$ & E-learning system &,------ & $\begin{array}{l}\text { Increase the development of technologies to be used in learn- } \\
\text { ing improvement }\end{array}$ \\
\hline
\end{tabular}




\section{$4 \quad$ Methodology Applied in Middle East Countries}

Oman is one of the Middle East countries, where all universities and higher colleges were in the middle of the second semester when the COVID-19 reached to the Middle East. However, all universities and higher colleges suggested procedure from the ministry of HEI recommended considering some marks based on the current course outcomes and the assessments already done in each program. Then they initiate a complementary procedure to continue in the evaluation with the remaining marks and with the policy of supporting students to improve their academic performance.

The ministry of HEI recommended considering some marks based on the current course outcomes and the assessments already done in each program. Then they initiate a complementary procedure to continue in the evaluation with the remaining marks and with the policy of supporting students to improve their academic performance.

In the current situation of learning with the COVID-19 pandemic, the whole time of teaching and learning changed to be an example from Al-Buraimi College (BUC) in Oman, and the daily class schedules remain as it is. The time duration of each class changed to be compact of 30 to 45 minutes per lecture. The regulation here is to give two weeks recorded lectures and uploaded on Moodle for all students on the class time, except one live stream class will be conducted for student's discussion and clarifications.

However, at Sohar University, the management decision-maker they proposed a short lesion to uploaded once in every two weeks with the concepts and significant points of each course and material. Besides, each faculty staff member was responsible for collecting student data records and generate WhatsApp groups for daily continuous discussion for the whole course procedure and fulfilment of the course requirements of assignments.

The time duration of each class changed to be compact of 30 to 45 minutes per lecture. The regulation here is to give two weeks recorded lectures and uploaded on Moodle for all students on the class time, except one live stream class will be conducted for student's discussion and clarifications. Besides, each institution has the responsibility to encourage the student to engage with e-learning and continuously test their behaviour intention to use e-learning system and its impact on their academic performance. Table 2 shows the adjusted schedule of the second semester of the academic year 2019'20 within the COVID-19 pandemic.

Table 2. BUC adjusted solution of completing the academic year by Adjusting classes

\begin{tabular}{|l|l|l|}
\hline & Before as Traditional teaching & \multicolumn{1}{c|}{ After COVID-19 as Online teaching } \\
\hline Time & 1.30 Hours & $30-45$ minutes \\
\hline Contents & All course material slides & Important topics with high quality \\
\hline Quality/ Quantity & Both are highly recommended & Recommending quality more than quantity \\
\hline Material & $\begin{array}{l}\text { A hard copy of the course material } \\
\text { power points+ book resources }\end{array}$ & Recorded lectures +URL of online related videos \\
\hline
\end{tabular}

Regarding the new situation, and as innovation solution, most of the middle east countries decide to follow the same rules and procedures. This study focuses on Oman 
as a sample of this solution. Still, with this COVID-19 pandemic situation, the whole college converted to be fully online classes. Even, the college mangers and college council, department committee, students' affairs, and all other departments in the college the conduct their work and discussed the critical of situation of learning challenges and student's problem through Google meet technology and all documents converted to soft copies and pdf files liable by id and order or meeting sequence, for the quality assurance purpose as pieces of evidence of university standards [19, 20].

Then, an opportunity to donate laptops from the college to the students who did not have personal laptops. After all these steps suggested by college managers and the college council, the level of students joins and actively increased to be $98 \%$ of the total students in the college. Another challenge was there, how to conduct exams and be sure that all students will join at the same time and they will solve the exams in a proper form? For this reason, the institutions decide as this semester of using online learning, not to conduct any quiz, and replaces all the assessment tools to be in multi-assignments given to the students as projects, case studies, or mathematical questions with suitable and enough time for student's response and participation.

Most of the studies presented by [21-26], they mentioned the whole work well studied on teaching methods. The student's satisfaction with the new material of pre-recorded lectures with attached files of PowerPoints, and Word versions of case studies, that can watch during their free time and guide them to solve their assignments. The aim of conducting live stream classes is to open discussion among students and to monitor their understanding, feedback, and their acceptance of this new procedure of learning. Besides, for practical courses, the whole education converted to use mixed between recording lectures and conducted next class as a live stream to be sure of all students understand the programming codes, and they downloaded the correct version of the language compiler. This technique also gives the students the flexibility to watch video lectures remotely at any time when they are free.

Table 3. Middle East Countries Institution Facilities

\begin{tabular}{|l|l|l|}
\hline & \multicolumn{1}{|c|}{ Before COVID-19 } & \multicolumn{1}{|c|}{ After COVID-19 } \\
\hline Computer use & $\begin{array}{l}\text { Labs usage by all students as their schedules } \\
\text { and classes }\end{array}$ & $\begin{array}{l}\text { Individual laptops offered for students } \\
\text { whose don't have PC }\end{array}$ \\
\hline Internet service & $\begin{array}{l}\text { All students have rights to login with college } \\
\text { internet service }\end{array}$ & $\begin{array}{l}\text { All internet labelled (edu) are free access } \\
\text { for all students in Oman }\end{array}$ \\
\hline Accessibility & $\begin{array}{l}\text { Students access on the right time of their class- } \\
\text { schedules }\end{array}$ & $\begin{array}{l}\text { Ayn time can be access and listen to the } \\
\text { lectures }\end{array}$ \\
\hline
\end{tabular}

Likewise, differentiation of instructing, how to make tweaked tasks to researchers at different levels, used to be extra testing and tedious. During internet educating, it used to be difficult to compose quite specific and far-reaching literary guidelines in upgrading understudies carrying out the responsibilities at home with the guide of themselves. Contrasted with up close and personal educating, the coach may need to never again be there for help, and encourage when required, and the spot directed [30]. 
Table 4. Student learning flexibility

\begin{tabular}{|l|l|l|}
\hline & \multicolumn{1}{|c|}{ Before COVID-19 } & \multicolumn{1}{c|}{ After COVID-19 } \\
\hline Attendance & Daily attendance & Not compulsory attendance \\
\hline Learning process & Individual efforts & Teamwork participations \\
\hline Assignments & Hardcopy quizzes & Open access reports and online quizzes \\
\hline Similarity reports & Not compulsory & Required to be $<=25 \%$ \\
\hline
\end{tabular}

\section{Innovative Solution}

In the second stage of student perceptions, they start accepting the situation and try to find a solution on how to adapt to online learning. This changes in perceptions came because the ministry offered the new policy to help students by:

1. Free internet use for all videos or materials with (.edu) as an extension.

2. Free time of access, and based on internet service quality and speed. Therefore, the students are free to join the platform Moodle at any time to watch the recorded lectures.

3. The evaluation process changed to be two assessment tools with the option to encourage the projects or reports about the topics offered without insisting on conducting live exams or compulsory attendance at specific times for evaluation of assignments.

4. Keep the hotline calls for giving support to the students who did not have personal computers of the good quality phone to be arranged by the college and ministry to provide full support by donating devices to this type of economy cases.

5. Encourage the students to work in teams and peer-to-peer support to overcome with the course material.

In the teachers and faculties section, the active work has been thriving for the span of the pandemic overcome using e-learning process [9, 24, and 40]. Tasks for the understudies have been adaptable, and advanced choices have utilized from numerous points of view [3, 9, and 41]. The pandemic has given encounters for the teachers which she wants to follow in ordinary study hall instructing later on. One of them is utilizing online frameworks for having tests [17].

Additionally, for animated understudies, the web offers boundless assets for different subjects. The educator figures she will use these sources in future instructing, as well. As web-based training used to be a triumph for a large number of the understudies, the instructor might want to see a likelihood to permit far off teaching days or spans for the understudies who truly advantage from and experience them later on [23-26, 42]. The instructors referred to the difficulties in going online inside days of the pandemic COVID-19. They needed to set up new schedules for themselves, arrange cases with understudies for online meetings, make week by week or fortnightly exercise plans for every understudy, and check and assess step by step or week by week [30, 43, 32].

There was furthermore no real way to send and receive things to the students at some phase in the lockdown as the majority stores had shut and roads. Teachers have entrusted with concocting imaginative and dynamic arrangements. Generally speaking, 
the teachers who work with youths with uncommon necessities, and educators, by and large, are showing flexibility and persistence, with regards to the acing and prosperity of their undergrads during this pandemic. The most significant weight they felt objectified to be yet to come - restarting with the essentials with students who were primarily abandoned [34-36, 44-46]. Figure 1, shows the university and quality assurance steps to solve teaching requirements and stages to get acceptance and approval with student behaviour intention to use e-learning system.

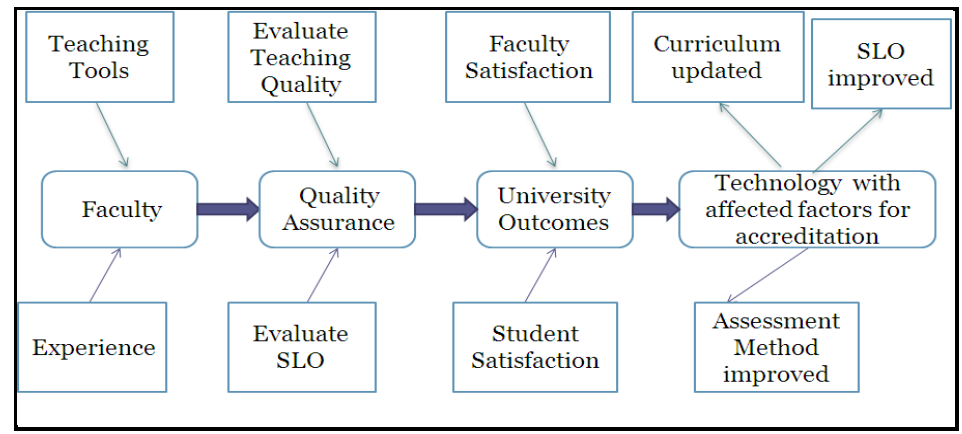

Fig. 1. Stages of Teaching and Learning Process for Behavior Intention to use e-learning

\section{Results and Impact}

The method of innovation solution technique is a link between university assessment standard and decision-makers to make full use of the e-learning system. The study stands on three main decision-makers. First, the university standard for developing its approval process based on behaviour intention to use e-learning system standards. Second, how much the percentage accuracy ratio could affect each available application which the enhanced algorithm suggested for students and TEL usage as e-learning ways. Third, the Moodle platform used to test the results to approve the effect of technology services in improving academic performance in terms of faculty and student satisfaction, and technology improvement and university outcomes. This point could implement by proposing a computational model of web-based survey research which is appropriate and widely accepted by researchers as an essential technique for researching some populations connected between features and TEL usability. 


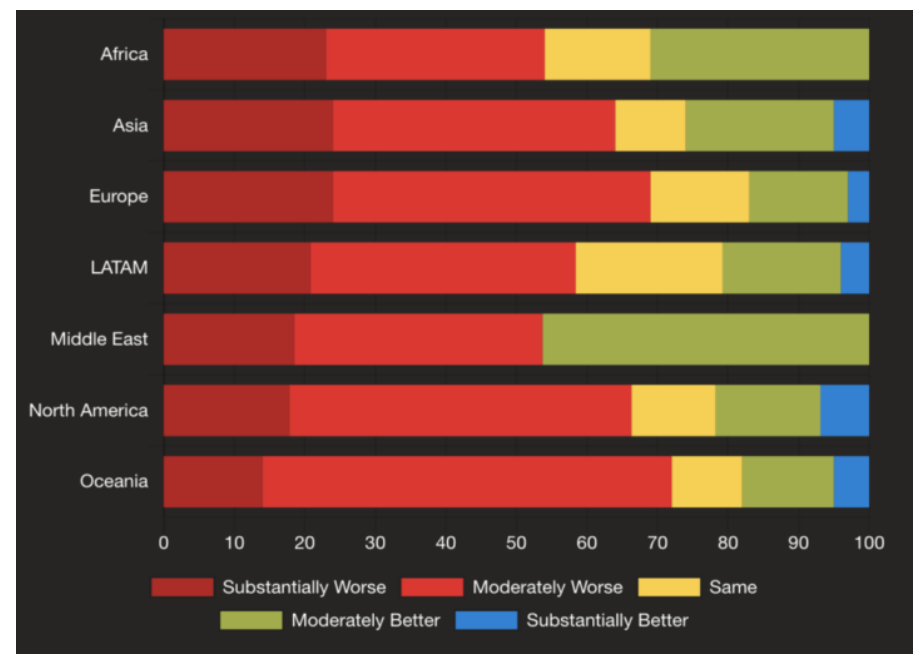

Fig. 2. Expected impacts of COVID-19 in Education Sectors

1. Student Learning Outcomes (Assessment Procedure): This standard is achieved by first determining whether the student skills accepted with his primary degree in the university or not. Secondly, if each course outcomes approved on the electronic portal system and the existence of a stamped hard copy report for each course result and achievement, thirdly, if electronic education used to improve skills, language, and performance [29].

2. Assessment Method (Assessment Instruments, and Procedures): This standard includes three phases - first, the placement test system comprising exams, tests, and quizzes. The second is the assessment report, assignments, and exercises evaluated individually or as a group. Thirdly, is the grade progress report; the progress report checks the student's situation if he/she is in a safe or under low GPA results [24-26].

3. Teaching Quality (Experience and Techniques): This standard includes two phases - first, the faculty experience and familiarity with the course material and required applications. Secondly, the level of understanding can improve different applications like Wiki chat, YouTube software, Google applications, and other media learning software that develop course descriptions and objectives.

\section{$7 \quad$ Findings}

Behaviour intention has identified as one of the most critical factors for e-learning system use and acceptance. The different use of technologies enhanced learning can support the whole leaning process by allowing using accessible technology and the suitable one based on the course complexity $[18,37,38]$. The finding given as follows:

1. In video-based applications, the weakness is the time for the extra work of audio files to record and disseminate by the class blogs. On the other side is the stress of not being able to upload videos. 
2. An individual chat recommended for students who are shy to ask questions or have a slip of initial idea - the reason for having a particular chat room.

3. Conduct an online peer moderator video blog to a group of participants.

4. Add a translator technique to convert student's voices to typed text. The Blog will make reading easy and reduce the time of typing and grammar effort. It also solves the problem of proper application pedagogy. This translator will make it easy to understand and arrange comments for scientific answers.

5. Increase the use of online contact to reduce asynchronous video-based blogging and documentation requirements. The live video chat and camera class share improved understanding and solve misunderstanding goals.

6. In online, peer evaluation program as TEL system still suffers from the difficulty of understanding people you have never met before. Sometimes, it is a waste of time because of ineffective communication and unclear roles. The solution to this challenge is to create a teamwork group with different options of selection (topic, friendship or personal knowledge, or intellectual in common subjects). As a suggestion, it needs faculty and assistant faculties to participate in many videos live chat or joint conferences to identify the struggles of course methodologies and roles. This chat included students to clarify all assessment required and tools of answers.

In the end, to compare this study methodology and innovative solutions with the research question. This study came out with the following findings:

Table 5. Summary of Finding regards Research Questions

\begin{tabular}{|c|l|l|}
\hline No. & \multicolumn{1}{|c|}{ Research Question } & \multicolumn{1}{|c|}{ Outcomes } \\
\hline 1 & $\begin{array}{l}\text { What is the TEL applied in colleges and universities } \\
\text { in conjunction with improving lab equipment and } \\
\text { administrative experience within the COVID-19 } \\
\text { pandemic? }\end{array}$ & $\begin{array}{l}\text { Enhancing the TEL use and multi e-learning } \\
\text { systems, platforms in Oman colleges and uni- } \\
\text { versities to overcome this pandemic situation. }\end{array}$ \\
\hline 2 & $\begin{array}{l}\text { What recommendations used with TEL mechanism } \\
\text { to convert to online teaching and learning? }\end{array}$ & $\begin{array}{l}\text { LMS used in Oman to control the learning and } \\
\text { teaching method. }\end{array}$ \\
\hline 3 & $\begin{array}{l}\text { What is the standard type of TEL data analysis } \\
\text { mostly used in universities and colleges? }\end{array}$ & $\begin{array}{l}\text { Mostly they used e-learning system, Moodle, } \\
\text { MOOC platforms. } \\
\text { Technology devices as Mobile use, Tablet, Fa- } \\
\text { cebook, and Gmail to contact students overall } \\
\text { the country. }\end{array}$ \\
\hline
\end{tabular}

\section{Conclusions and Recommendations}

The role of behaviour intention of students in consuming e-learning system as an alternative option for fighting with the COVID-19 pandemic explored in this article. Al Buraimi College, as a private university, was selected to analyze the procedure of teaching and learning for BUC students. The methodology and suggested models identified the challenges faced in converting traditional on-campus classes to fully online learning.

This study explained the exceptional circumstance with the current state in both schools and higher educational institutions. The incorporation of TEL has changed the 
way of learning from traditional teaching method to fully online learning method. The smart practised followed by various countries, the challenges faced in the e-learning process in each stage and each country discretely based on the level of commencement of flexibility and usability of internet use and their acceptance to move towards online learning also explored in this article.

The research conducted on undergraduate students; a similar study can undertake in various domains such as business, information technology, engineering, law, and social studies. Even though COVID 19 is a health crisis, it affected almost all fields like business, information, politics, economy, entertainment, etc. and that too worldwide. So there is a more significant opportunity for researches on each domain and also country wise.

\section{Acknowledgement}

The researchers at University Malaysia Pahang (UMP) conduct the research reported in this study, it funded by RDU1903116 grant. The researchers would like to thank the Ministry of Higher Education and UMP for supporting this research.

\section{References}

[1] McKibbin, W. J., \& Fernando, R. (2020). The global macroeconomic impacts of COVID19: Seven scenarios.

[2] Tawafak, Ragad M., A. B. Romli, Ruzaini bin Abdullah Arshah, and Rana A. Saeed Almaroof. "Assessing the impact of technology learning and assessment method on academic performance." EURASIA Journal of Mathematics, Science and Technology Education 14, no. 6 (2018): 2241-2254. https://doi.org/10.29333/ejmste/87117

[3] Porpiglia, F., Checcucci, E., Amparore, D., Verri, P., Campi, R., Claps, F., ... \& Mario Scarpa, R. (2020). The slowdown of urology residents' learning curve during the COVID19 emergency. BJU international. https://doi.org/10.1111/bju.15076

[4] Tawafak, Ragad M., Awanis Romli, Sohail Iqbal Malik, Mohanaad Shakir, and Ghaliya M. Alfarsi. "A systematic review of personalized learning: Comparison between E-learning and learning by coursework program in Oman." International Journal of Emerging Technologies in Learning (iJET) 14, no. 09 (2019): 93-104. https://doi.org/10.3991/ijet.v14i09. $\underline{10421}$

[5] Oman Academic Accreditation Authority. (2010). Retrieved 1 1, 2010, from www.oaaa Oman: http://www.oaaa.gov.om/ar/Default.aspx

[6] Tawafak, R. M., Romli, A., \& Arshah, R. A. (2019, August). E-learning prospect on improving academic performance in Omani Universities. In IOP Conference Series: Materials Science and Engineering (Vol. 551, No. 1, p. 012033). IOP Publishing. https://doi.org/10.1088/1757-899x/551/1/012033

[7] Zhu, N., Zhang, D., Wang, W., Li, X., Yang, B., Song, J., ... \& Niu, P. (2020). A novel coronavirus from patients with pneumonia in China, 2019. New England Journal of Medicine.

[8] Tawafak, Ragad M., Awanis M. Romli, and Maryam Juma Alsinani. "Student Assessment Feedback Effectiveness Model for Enhancing Teaching Method and Developing Academic 
Performance." International Journal of Information and Communication Technology Education (IJICTE) 15, no. 3 (2019): 75-88. https://doi.org/10.4018/ijicte.2019070106

[9] Kalogiannakis, M., \& Papadakis, S. (2019). Evaluating pre-service kindergarten teachers' intention to adopt and use tablets into teaching practice for natural sciences. International Journal of Mobile Learning and Organisation, 13(1), 113-127. https://doi.org/10.1504/ ijmlo.2019.10016617

[10] Tawafak, Ragad M., Awanis BT Romli, and Ruzaini Bin Abdullah Arshah. "Continued Intention to use UCOM: Four factors for integrating with a technology acceptance model to moderate the Satisfaction of Learning." IEEE Access 6 (2018): 66481-66498. https://doi.org/10.1109/access.2018.2877760

[11] Azorín, C. (2020). Beyond COVID-19 supernova. Is another education coming? Journal of Professional Capital and Community. https://doi.org/10.1108/jpcc-05-2020-0019

[12] Tawafak, Ragad M., Muamer N. Mohammed, Ruzaini bin Abdullah Arshah, and Awanis Romli. "Review on the effect of student learning outcome and teaching Technology in Omani's higher education Institution's academic accreditation process." In Proceedings of the 2018 7th International Conference on Software and Computer Applications, pp. 243247. 2018. https://doi.org/10.1145/3185089.3185108

[13] Tawafak, R. M., Romli, A. B., \& Arshah, R. B. A. (2019, February). E-learning Model for Students' Satisfaction in Higher Education Universities. In 2019 International Conference on Fourth Industrial Revolution (ICFIR) (pp. 1-6). IEEE. https://doi.org/10.1109/ icfir.2019.8894778

[14] Alfarsi, G., Sulaiman, H., Tawafak, R. M., Malik, S., Jabbar, J., \& Alsidiri, A. (2019). A Study of Learning Management System with E-Learning.

[15] Mathew, R., Malik, S. I., \& Tawafak, R. M. (2019). Teaching Problem Solving Skills using an Educational Game in a Computer Programming Course. Informatics in Education, 18(2), 359. https://doi.org/10.15388/infedu.2019.17

[16] Torous, J., Myrick, K. J., Rauseo-Ricupero, N., \& Firth, J. (2020). Digital mental health and COVID-19: Using technology today to accelerate the curve on access and quality tomorrow. JMIR mental health, 7(3), e18848. https://doi.org/10.2196/18848

[17] Chen, L. T., \& Liu, L. (2020). Social Presence in Multidimensional Online Discussion: The Roles of Group Size and Requirements for Discussions. Computers in the Schools, 1-25. https://doi.org/10.1080/07380569.2020.1756648

[18] Malik, S. I., Al-Emran, M., Mathew, R., Tawafak, R. M., \& AlFarsi, G. (2020). Comparison of E-Learning, M-Learning and Game-based Learning in Programming Education: A Gendered Analysis. International Journal of Emerging Technologies in Learning, (15). https://doi.org/10.3991/ijet.v15i15.14503

[19] Goh, P. S., \& Sandars, J. (2020). A vision of the use of technology in medical education after the COVID-19 pandemic. MedEdPublish, 9. https://doi.org/10.15694/mep. $\underline{2020.000049 .1}$

[20] Tawafak, R. M., Malik, S. I., \& Alfarsi, G. (2020). Development of Framework from Adapted TAM with MOOC Platform for Continuity Intention. Development, 29(1), 16811691.

[21] Tawafak, R. M., AlSideir, A., Alfarsi, G., Al-Nuaimi, M. N., Malik, S. I., \& Jabbar, J. (2019). E-learning Vs. Traditional Learning for Learners Satisfaction. E-learning, 29(3), 388-397.

[22] Almarzooq, Z., Lopes, M., \& Kochar, A. (2020). Virtual learning during the COVID-19 pandemic: a disruptive technology in graduate medical education.

[23] Clustering, A. S., 2019 International Arab Conference on Information Technology (ACIT). Higher Education, 165, 170. 
[24] Tatnall, A. (2020). Editorial for EAIT issue 2, 2020. Education and Information Technologies, 25(2), 647-657. https://doi.org/10.1007/s10639-020-10135-1

[25] Tatnall, A. (2019). Editorial for EAIT issue 2, 2019. Education and Information Technologies, 24(2), 953-962. https://doi.org/10.1007/s10639-019-09874-7

[26] Tawafak, R. M., Romli, A. B., Abdullah, R., Alfarsi, G., Jabbar, J., Esbai, R., ... \& Abdelhameed, W. Competitiveness \& Quality.

[27] Al Farsi, G., Jabbar, J., Tawafak, R. M., Malik, S. I., Alsidiri, A., \& Alsinani, M. (2020). Mobile Application System Supported BUC Students Services and Learning. International Journal of Interactive Mobile Technologies, 14(9). https://doi.org/10.3991/ijim.v14 $\underline{\mathrm{i} 09.12053}$

[28] Tawafak, R. M., Alfarsi, G., AlNuaimi, M. N., Eldow, A., Malik, S. I., \& Shakir, M. (2020, April). Model of Faculty Experience in E-Learning Student Satisfaction. In 2020 International Conference on Computer Science and Software Engineering (CSASE) (pp. 83-87). IEEE. https://doi.org/10.1109/csase48920.2020.9142071

[29] Chick RC, Peace KM, Kemp Bohan PM, et al. Trainee Perception and Efficacy of a Flipped Classroom Model in General Surgery Academic Conferences, 2020. Seattle, WA: Association for Surgical Education; 2020.

[30] Chick, R. C., Clifton, G. T., Peace, K. M., Propper, B. W., Hale, D. F., Alseidi, A. A., \& Vreeland, T. J. (2020). Using technology to maintain the education of residents during the COVID-19 pandemic. Journal of Surgical Education. https://doi.org/10.1016/j.jsurg. $\underline{2020.03 .018}$

[31] Wang, C. J., Ng, C. Y., \& Brook, R. H. (2020). Response to COVID-19 in Taiwan: big data analytics, new technology, and proactive testing. Jama, 323(14), 1341-1342. https://doi.org/10.1001/jama.2020.3151

[32] Park, S., Choi, G. J., \& Ko, H. (2020). Information technology-based tracing strategy in response to COVID-19 in South Korea-privacy controversies. Jama. https://doi.org/10. 1001/jama.2020.6602

[33] Eldow, Abdalla, Mohanaad Shakir, Mohammed Ahmed Talab, Ahmed Kh Muttar, and Ragad M. Tawafak. "Literature Review of Authentication Layer for Public Cloud Computing: A Meta-Analysis." (2006).

[34] Huang, R. H., Liu, D. J., Tlili, A., Yang, J. F., \& Wang, H. H. (2020). Handbook on facilitating flexible learning during educational disruption: The Chinese experience in maintaining undisrupted learning in COVID-19 Outbreak. Beijing: Smart Learning Institute of Beijing Normal University.

[35] Iivari, N., Sharma, S., \& Ventä-Olkkonen, L. (2020). Digital transformation of everyday life-How COVID-19 pandemic transformed the primary education of the young generation and why information management research should care? International Journal of Information Management, 102183. https://doi.org/10.1016/j.ijinfomgt.2020.102183

[36] Ting, D. S. W., Carin, L., Dzau, V., \& Wong, T. Y. (2020). Digital technology and COVID19. Nature medicine, 26(4), 459-461. https://doi.org/10.1038/s41591-020-0824-5

[37] Tian, S., Hu, N., Lou, J., Chen, K., Kang, X., Xiang, Z., ... \& Chen, G. (2020). Characteristics of COVID-19 infection in Beijing. Journal of Infection.

[38] Teräs, M., Suoranta, J., Teräs, H., \& Curcher, M. (2020). Post-COVID-19 Education and Education Technology 'Solutionism': A Seller's Market. Postdigital Science and Education, 1-16. https://doi.org/10.1007/s42438-020-00164-x

[39] Jabbar, J., Malik, S. I., AlFarsi, G., \& Tawafak, R. M. The Impact of WhatsApp on Employees in Higher Education. In Recent Advances in Intelligent Systems and Smart Applications (pp. 639-651). Springer, Cham. https://doi.org/10.1007/978-3-030-47411-9_34 
[40] Kalogiannakis, M., \& Papadakis, S. (2007, June). The dual form of further education of educators in ICT: technological and pedagogical training. In C. Constantinou, Z. Zacharias $\&$ M. Papaevripidou (Eds.) Proceedings of the 8th International Conference on ComputerBased Learning in Science, Heraklion (Vol. 30, pp. 265-276).

[41] Papadakis, S., Kalogiannakis, M., Sifaki, E., \& Vidakis, N. (2018). Evaluating Moodle use via Smart Mobile Phones. A case study in a Greek University. EAI Endorsed Transactions on Creative Technologies, 5(16). https://doi.org/10.4108/eai.10-4-2018.156382

[42] Papadakis, S., Kalogiannakis, M., Sifaki, E., \& Vidakis, N. (2017). Access moodle using smart mobile phones - a case study in a Greek University. In Interactivity, Game Creation, Design, Learning, and Innovation (pp. 376-385). Springer, Cham. https://doi.org/10. 1007/978-3-319-76908-0_36

[43] Papadakis, S., \& Kalogiannakis, M. (2020). A Research Synthesis of the Real Value of SelfProclaimed Mobile Educational Applications for Young Children. In Mobile Learning Applications in Early Childhood Education (pp. 1-19). IGI Global. https://doi.org/10.4018/ 978-1-7998-1486-3.ch001

[44] Kalogiannakis, M., \& Papadakis, S. (2020). The Use of Developmentally Mobile Applications for Preparing Pre-Service Teachers to Promote STEM Activities in Preschool Classrooms. In Mobile Learning Applications in Early Childhood Education (pp. 82-100). IGI Global. https://doi.org/10.4018/978-1-7998-1486-3.ch005

[45] Papadakis, S. (2018). Evaluating pre-service teachers' acceptance of mobile devices with regards to their age and gender: a case study in Greece. International Journal of Mobile Learning and Organisation, 12(4), 336-352. https://doi.org/10.1504/ijmlo.2018. 10013372

[46] Lezzar, F., Benmerzoug, D., \& Kitouni, I. (2020). IoT for Monitoring and Control of Water Quality Parameters. International Journal of Interactive Mobile Technologies, 14(16). https://doi.org/10.3991/ijim.v14i16.15783

[47] Utomo, B., Wibowo, A. T., Ridwan, M., Izzuddin, M. A., Gumelar, A. B., \& Arifin, S. (2020). Enhanced of Attendance Records Technology used Geospatial Retrieval based on Crossing Number. International Journal of Interactive Mobile Technologies, 14(16). https://doi.org/10.3991/ijim.v14i16.13911

[48] Syaifudin, Y. W., Yunhasnawa, Y., Pramitarini, Y., Setiawan, A., Rohadi, E., \& Saputra, P. Y. (2020). A Proposed Framework of Campus-Oriented Online Text Messaging System. International Journal of Interactive Mobile Technologies, 14(16). https://doi.org/10. 3991/ijim.v14i16.11454

[49] Tawafak, R. M., Buraimi, O., Jabbar, J., Alfarsi, G., Malik, S. I., Romli, A., \& Alsideiri, A. A Review Paper on Student-Graduate Advisory Expert system. https://doi.org/10. 1109/iccit-144147971.2020.9213794

[50] Tawafak, R., Romli, A., Malik, S., \& Shakir, M. (2020). IT Governance Impact on Academic Performance Development. International Journal of Emerging Technologies in Learning (iJET), 15(18), 73-85. https://doi.org/10.3991/ijet.v15i18.15367

[51] Alfarsi, G., Jabbar, J., Tawafak, R. M., Malik, S. I., Alsidiri, A., \& Alsinani, M. Using Cisco Packet Tracer to simulate Smart Home. https://doi.org/10.1109/acit47987.2019. $\underline{8990975}$ 


\section{Authors}

Ragad M Tawafak holds a PhD. Degree in computer science. She is expert in ELearning, Mobile Application, Knowledge Management, etc. Email: raghad@buc.edu.om

Ghaliya Alfarsi has MSc. Degree in computer science. She is expert in E-Learning, Mobile Application, Knowledge Management, etc.

Jasiya Jabbar is expert in E-Learning, Mobile Application, Knowledge Management, etc.

Sohail Iqbal Malik has a PhD. Degree in computer science. Also, he is expert in ELearning, Mobile Application, Knowledge Management, etc.

Roy Mathew holds a PhD degree in computer science. He is expert in E-Learning, Mobile Application, Knowledge Management, etc.

Abir Alsideiri is a master degree holder, and an expert in image processing, machine language and e-learning.

Mohanaad Shakir has a PhD degree in Security of computer science. He is expert of security, and e-learning.

Awanis BT Romli has a PhD. In computer science and interest in digital green infrastructure, E-learning, Mobile applications, etc.

Article submitted 2020-08-17. Resubmitted 2020-10-23. Final acceptance 2020-10-24. Final version published as submitted by the authors. 